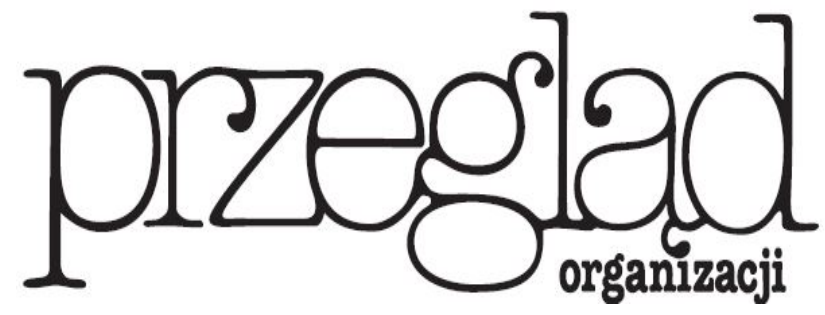

Miesięcznik TNOiK Założył Karol Adamiecki w 1926 r.

\title{
INTEGRACJA KANALÓW W MODELU SPRZEDAŻY OMNICHANNEL
}

https://doi.org/10.33141/po.2019.08.03

Mieczysław Pawłowski, Zbigniew Pastuszak
Przegląd Organizacji, Nr 8 (955), 2019, ss.18-25 www.przegladorganizacji.pl oTowarzystwo Naukowe Organizacji i Kierownictwa

(TNOiK)

\section{Wprowadzenie}

$\mathbf{P}$

ojęcie integracji kanałów definiuje się jako informowanie klientów kanału online o kanale offline wraz z możliwością dostępu do funkcji tego kanału oraz informowanie klientów kanału offline o kanale online wraz $\mathrm{z}$ umożliwieniem interakcji w tym kanale (Herhausen i in., 2015, s. 309-310). Integrację kanałów można osiągnąć poprzez wskazywanie internautom lokalizacji sklepów sieci stacjonarnej, informowanie o dostępności produktów we wskazanych lokalizacjach czy też umożliwienie złożenia zamówienia $\mathrm{z}$ opcją odbioru własnego i zapłaty w sklepie. Integrację ze strony sieci sprzedaży stacjonarnej do kanału online można osiągnąć poprzez udostępnienie środowiska online w sklepie, a w szczególności umożliwienie wykorzystania informacji produktowej, przejrzenia rekomendacji lub samodzielnego wykorzystania funkcji dostępnych w sklepie internetowym. W systemach zintegrowanych powinna istnieć możliwość rozpoczęcia zakupu, rozpoznania produktów, kontynuacji procesu oraz samodzielnego zakończenia i zapłaty z wykorzystaniem smartfonów. Smartfony można traktować także jako urządzenia skanujące lub wchodzące $\mathrm{w}$ interakcję radiową $\mathrm{z}$ infrastrukturą teleinformatyczną sklepu stacjonarnego. Stopień współdziałania środowiska fizycznej i wirtualnej obsługi klienta można nazwać poziomem integracji. Integrację kanałów kreuje 
również koordynacja kanałów, której celem jest wykorzystanie całego ekosystemu biznesowego przedsiębiorstwa do uzyskania dodatkowych korzyści wynikających z synergii współpracy różnorodnych elementów całego systemu.

System sprzedaży typu omnichannel, zintegrowany i wielokanałowy, składa się zazwyczaj z trzech głównych kanałów: 1) sieci sklepów stacjonarnych, 2) sklepu i katalogu internetowego wraz z call center oraz 3) przedstawicieli handlowych działających w terenie. Taka organizacja handlu, zapoczątkowana na rynku detalicznym, przenika obecnie do sprzedaży w modelu biznes-dla-biznesu, B2B (Prałat, 2017, s. 500-510). Model ten powstaje najczęściej w wyniku ewolucji modelu wielokanałowego w ten sposób, że interakcje dowolnego etapu procesu zakupowego są rozpatrywane, planowane i realizowane $z$ punktu widzenia kontynuacji kontaktu z marką, a nie $\mathrm{z}$ kanałem sprzedaży (Piotrowicz, Cuthbertson, 2014, s. 6).

Celem artykułu jest analiza zjawiska integracji kanałów jako kompleksu czynników budujących przewagę konkurencyjną przedsiębiorstwa na rynku oraz dostarczających większej wartości dla klientów (w kontekście funkcjonalnym). Autorzy dokonali przeglądu literatury oraz przeprowadzili badania własne na wybranym rynku B2B.

\section{Integracja kanałów jako zagadnienie badawcze}

$\mathbf{R}$ ozwój form sprzedaży wielokanałowej znajduje swoje odzwierciedlenie w wielu pracach badawczych. P.C. Verhoef i inni (2015, s. 174-181) opisują rozwój, opracowywanie i zarządzanie kanałami w różnych formach - od separacji po omnichannel. Rozbudowa systemu sprzedaży w którymkolwiek kanale może wpływać na zachowania klientów we wszystkich kanałach (Cao, Li, 2015, s. 5). Istnieje pewna liczba prac, których wyniki można odnieść do tego aspektu aktywności zintegrowanych kanałów dystrybucji, ale dotyczą one głównie zarządzania cenami i dostępnością produktów w zintegrowanych kanałach (Pan i in., 2004, s. 124). Tymczasem, wraz ze wzrostem popularności smartfonów i aplikacji mobilnych, obserwowane jest znaczne nasilenie oczekiwań klientów, dotyczących swobodnego przechodzenia między kanałami w procesie zakupu. Klienci intensywnie wykorzystują tzw. webrooming do kompleksowego rozpoznania przedzakupowego oraz wizyty w sklepach sieci stacjonarnej w celu osobistego sprawdzenia swoich wyborów - tzw. showrooming (Verhoef i in., 2007, s. 130). Integracja kanałów ma w tym przypadku decydujące znaczenie dla spójnego postrzegania dostawcy jako solidnego i skutecznego oferenta; umożliwia także płynną realizację procesu zakupu (Neslin i in., 2006, s. 95-112).

Integracja kanałów może być rozpatrywana $\mathrm{z}$ perspektywy klienta oraz firmy. Podejście klientocentryczne koncentruje się na zarządzaniu klientami i relacjami w układzie klient-przedsiębiorstwo. Przedsiębiorstwo analizuje i stymuluje relokację klientów między kanałami w celu dostarczenia maksymalnych korzyści (wartości) wynikających z synergicznego wykorzystania atrybutów kanałów i właściwego odczytania oczekiwań klientów
(Kumar, 2010, s. 134-150). Podejście firmocentryczne skupia się na korzyściach dla firmy. W tym przypadku, poprzez wykorzystanie skali działalności, kosztowego dopasowania kanałów do specyfiki klientów i starannego wykorzystania synergii zasobów, firma jest w stanie generować większe zyski, wynikające z modelu integracji obsługi klienta (Neslin, Shankar, 2009, s. 75).

Integracja kanałów powinna kreować wartość dla klienta oraz przewagę konkurencyjną firmy. Elementem przewagi konkurencyjnej jest postrzeganie marki. Na postrzeganie marki ma oczywiście wpływ: zawartość marki, obietnica i reputacja marki na rynku. Zintegrowany model sprzedaży wzmacnia pozytywne postrzeganie marki, na co wskazuje teoria rozszerzania marki. Jeśli marka spełnia oczekiwania jakościowe klienta w jednym kanale, to fakt ten jest przenoszony także na inne kanały (Yang i in., 2013, s. 858-869).

Można określić trzy główne czynniki wpływające na wybór dostawcy; są to: atrybuty kanału, w którym będą realizowane zakupy, zablokowanie klienta oraz integracja (Verhoef i in., 2007, s. 130). Atrybuty kanału, czyli jego właściwości, powinny być ściśle skorelowane z potrzebami grup klientów, do których dany kanał jest dedykowany. Profilowanie kanału pod określoną grupę klientów zabezpiecza jego zakładaną rentowność. Wynika to $\mathrm{z}$ dopasowania wyposażenia kanału oraz wynikających z tego kosztów bieżących do zachowania zakupowego klientów i absorpcji aktywności kanałów w przewidziany i racjonalny sposób. Zablokowanie klienta odnosi się do sytuacji, w której klient musi realizować zakupy w określonym kanale ze względu na okoliczności od niego niezależne. Integracja pozwala na utrzymanie klienta, który jest niezadowolony z aktualnie wykorzystywanego kanału, ale ceni sobie dostawcę. Zintegrowany model sprzedaży daje rozszerzone możliwości migracji klienta do innego kanału. Zmiana kanału może przywrócić zadowolenie klienta, może także wynikać z preferencji klienta co do sposobu obsługi. Pozostawanie klienta $\mathrm{w}$ relacji z wypróbowanym dostawcą, nawet w sytuacji wymuszonego przejścia do innego kanału, niesie za sobą mniejsze koszty niż zmiana dostawcy. Można to wyjaśnić na podstawie teorii księgowania mentalnego oraz kosztów przejścia (tzw. mental accounting, Thaler, 2008, s. 15-30) - klienci tworzą umysłowy model ryzyk, który w tym przypadku preferuje zakupy u aktualnego dostawcy. Nawet wymuszona zmiana kanału sprzedaży, w znanym środowisku, nie odstrasza klineta. Jest to dla niego mniej ryzykowane niż nawiązywanie od początku relacji z nowym dostawcą. Przejście do innego dostawcy zawiera wiele niewiadomych, które powodują dyskomfort. Pionierskie badania dotyczące podejmowania decyzji pod presją ryzyka prowadzili D. Kahneman i A. Tversky (1979, s. 263-291), ale oczywiście doczekały się one później wielu rozszerzonych analiz (Gärdenfors, 2005; Wang, Webster, 2007; Bezes, 2016; Ramanathan, 2011). Potwierdzają oni istnienie dużych oporów mentalnych, wynikających z natury człowieka, do przeprowadzenia zmiany obarczonej ryzykiem, nawet pomimo uprawdopodobnionej perspektywy osiągnięcia większych korzyści. Jeśli chodzi o relacje B2B, można 
także brać pod uwagę czynniki o charakterze relacyjnym między pracownikami przedsiębiorstw (Kim i in., 2010, s. 863-869).

Analiza treści wskazanych opracowań, jak również doświadczenie zawodowe autorów tekstu umożliwily sformułowanie problemu badawczego, odwołującego się do zależności między integracją kanałów dystrybucji a postrzeganiem integracji przez klientów przedsiębiorstwa jako wartości dla nich. Innymi słowy, autorzy podjęli próbę odpowiedzi na pytanie, jakie elementy systemów sprzedaży $\mathrm{w}$ modelu omnichannel decydują o postrzeganiu integracji jako wartościowej dla klienta i w jakim stopniu integracja ta wpływa na skłonność klienta do rekomendacji/dokonania zakupu, a tym samym - wspierania wzrostu pozycji konkurencyjnej przedsiębiorstwa.

\section{Metoda badawcza}

W pracy sformułowano i podjęto próbę empirycznej weryfikacji tezy badawczej w brzmieniu: możliwe jest wykorzystanie współczynnika integracji kanałów dystrybucji do wspomagania tworzenia przewagi konkurencyjnej przedsiębiorstwa $\mathrm{w}$ systemie dystrybucji omnichannel na rynku usług B2B.

$\mathrm{Na}$ podstawie analizy literatury, przeglądu funkcji dostępnych w systemach obsługi wielokanałowej, prezentowanych np. w badaniach Gemius dla e-Commerce Polska (s. 71-99), oraz w oparciu o własne doświadczenia praktyczne autorzy niniejszej pracy sformułowali listę funkcji integrujących, które powinny być zaimplementowane w systemach wielokanałowych w celu dostarczania oczekiwanej wartości dla klientów:

1. Możliwość zakupu online oraz odbioru i zapłaty w punkcie sieci stacjonarnej.

2. Dostęp do centralnej pomocy telefonicznej obejmującej sieć stacjonarną, sieć przedstawicieli handlowych $\mathrm{w}$ terenie oraz zakupy online.

3. Możliwość zwrotu produktów kupionych online w dowolnym punkcie sieci stacjonarnej.

4. Prezentacja dostępności produktów ze sklepów sieci stacjonarnej na stronach internetowych.

5. Objęcie programem lojalnościowym zakupów w sieci stacjonarnej oraz online.

6. Umożliwienie wykorzystania smartfonów lub innych urządzeń dostępnych w sklepie do przeglądania sklepu online oraz dostępności produktów w innych sklepach sieci stacjonarnej.

7. Udostępnienie możliwości zakupu lub rezerwacji z poziomu sklepu internetowego, także produktów dostępnych w sieci stacjonarnej.

8. Umożliwienie zakupu $\mathrm{w}$ sklepie stacjonarnym za pomocą smartfonu $\mathrm{z}$ opcją zapłaty internetowej, bez czekania przy kasie.

Lista tych funkcji została wykorzystana do sformułowania ankiety badawczej, wykorzystanej do przeprowadzenia autorskich badań empirycznych na próbie klientów firmowych (B2B), operujących na rynku handlu materiałami budowlanymi. Rynek ten wybrano $\mathrm{z}$ dwóch powodów. Po pierwsze, przedstawia on wartość ok. 20 mld zł, z czego ok. 11,5 mld zł stanowi wartość rynku materiałów dla instalacji grzewczych i sanitarnych (Systemy Instalacyjne, 2019), a około 7-8 mld zł - rynek elektrotechniki (RI Grodno, 2019). Dodatkowo na rynku tym działa wielu dystrybutorów (Elektrosystemy, 2018; Elektroklub, 2017), z udziałem liderów rynkowych (około 8 firm) na poziomie około 5-8\%. Drugim argumentem był fakt posiadania przez autorów doświadczeń praktycznych (w tym dot. zarządzania systemem sprzedaży wielokanałowej $\mathrm{w}$ przedsiębiorstwie, które jest jednym z liderów sprzedaży wielokanałowej w Polsce), umożliwiających sprawną realizację badań podmiotów działających na rynku, a w szczególności gwarantujących zapewnienie wiarygodności uzyskanych wyników (możliwość identyfikacji poziomu zawodowego i kwalifikacji respondentów).

Badania empiryczne przeprowadzono metodą CAWI, poprzez umieszczenie ankiety - zawierającej 8 pytań, odwołujących się do wymienionych funkcji integrujących - w sklepie internetowym B2B jednego z największych polskich dystrybutorów materiałów budowlanych, przeznaczonych w szczególności dla instalatorów. Klienci sklepu posiadali doświadczenie z szerszego rynku, ponieważ dokonywali również zakupów w sklepach innych dystrybutorów. Znane były im także formy interakcji z dostawcami $\mathrm{w}$ sklepach stacjonarnych, relacje realizowane poprzez e-mail, kontakt telefoniczny $z$ handlowcami oraz platformy zakupów internetowych różnych dostawców.

Badane firmy prowadziły działalność w różnych miejscowościach, oferując swoje usługi na obszarze całej Polski. W wykorzystanym w trakcie badań sklepie internetowym podmiotowego dystrybutora, wykonywało zakupy około 200 klientów dziennie. Do wypełnienia ankiety zachęcało ogłoszenie widoczne na stronie sklepu w ciągu pięciu dni. Badania zrealizowano w końcu grudnia 2018 r. Klienci wypełniali ankietę dobrowolnie, bez wymuszenia ich aktywności przez system informatyczny.

Tabela 1. Charakterystyka próby badawczej

\begin{tabular}{|l|c|c|}
\hline \multicolumn{1}{|c|}{ Grupa przedsiębiorstw } & Liczba firm & Udziat $\left(\mathbf{N}_{\%}\right)$ \\
\hline Usługowe $\left(\mathbf{N}_{\mathrm{U}}\right)$ & 49 & $58,3 \%$ \\
\hline Handlowe $\left(\mathrm{N}_{\mathbf{H}}\right)$ & 35 & $41,7 \%$ \\
\hline Razem $\left(\mathbf{N}_{\mathrm{T}}\right)$ & 84 & $100,0 \%$ \\
\hline Zakupy miesięczne B2B & Liczba firm & Udział $\left(\mathbf{N}_{\%}\right)$ \\
\hline$<=10000$ PLN & 43 & $52,0 \%$ \\
\hline $10001-100000$ PLN & 36 & $42,9 \%$ \\
\hline Pow. 100 000 PLN & 5 & $6,0 \%$ \\
\hline Razem & 84 & $100,0 \%$ \\
\hline
\end{tabular}

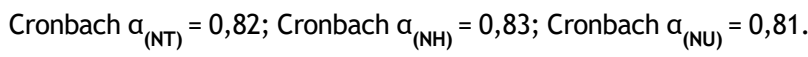
Źródło: opracowanie własne

Charakter działalności przedsiębiorstwa, za pośrednictwem którego zrealizowano badania (ok. 5\% udział w rynku sklepów specjalistycznych) zapewniał celowy 
dobór próby, składającej się z firm handlowych i usługowych, które mogły korzystać $\mathrm{z}$ wielokanałowości na całym rynku w celu pozyskiwania towarów do swojej działalności (było to podstawowym kryterium doboru próby, realizującym cel badania). $Z$ danych wewnętrznych dystrybutora wynika, że zebrana próba badawcza pokrywa około $15,4 \%$ całkowitych obrotów realizowanych w kanale internetowym oraz około $6,0 \% \mathrm{w}$ sprzedaży całkowitej (pomijając sprzedaż projektową, która jest realizowana metodą jednokanałową na dużą skalę). Próba badawcza została scharakteryzowana $\mathrm{w}$ tabeli 1. Zebrane odpowiedzi wykazują dużą zbieżność (alfa Cronbacha wynosi 0,82 dla całej badanej próby, a w poszczególnych grupach klientów: 0,83 dla firm handlowych i 0,81 dla firm usługowych).

\section{Wyniki badań}

W procesie analizy zgromadzonych wyników wykorzystano podejście bazujące na procedurze badań satysfakcji klientów, zrealizowanych na rynku czeskim (Faltejsková i in., 2016, s. 96) z wykorzystaniem zaproponowanej przez ich autorów formuły. Klienci wyrażali swoją opinię na temat przydatności poszczególnych funkcji integracyjnych, korzystając z uproszczonej skali pojęciowej o wartościach: "funkcja nieprzydatna", ,funkcja przydatna" oraz "funkcja bardzo przydatna", którą przekształcono na skalę liczbową, wyrażoną wagami o wartościach: $\{-1,1$ i 2$\}$. Satysfakcję klienta, wyrażoną poprzez ocenę funkcji integracyjnych, obliczono jako sumę ocen poszczególnych funkcjonalności, według wzoru:

$$
\varepsilon_{j}=\frac{\sum_{i=1}^{n} \mathrm{~V}_{i j} \mathrm{X}_{i j}}{2 n}
$$

gdzie:

$\varepsilon_{j}$ - wskaźnik satysfakcji klienta (j-tego przedsiębiorstwa); wartość bezwzględna,

$V_{i j}$ - waga (-1, 1 i 2$) i$-tej mierzonej zmiennej (oceny funk-

cji integrujących; od 1 do 8) dla j-tego przedsiębiorstwa

(z poszczególnych podgrup próby - tabela 1 ),

$X_{i j}$ - ocena pojęciowa przydatności i-tej funkcji (mierzonej zmiennej), jaką wskazało $j$-te przedsiębiorstwo,

$n$ - liczba mierzonych zmiennych (pytań, tj. funkcji integrujących).

Do interpretacji poziomu satysfakcji klienta zastosowano pomocniczo współczynnik NPS (Net Promoter Score; Bergevin i in., 2010, s. 345). Wykorzystuje on 10-stopniową skalę liniową, w której oceny 0-6 wskazują populację krytyków danego rozwiązania, oceny 7-8 wskazują postawę obojętną lub umiarkowanych zwolenników, a tylko oceny 9-10 wyróżniają promotorów danego rozwiązania lub danej marki. NPS oblicza się, jako różnicę procentowego udziału promotorów i krytyków (tj. przybiera on wartości z zakresu: od minus 100\% do plus 100\%). Podobnie wskaźnik satysfakcji klienta $\left(\varepsilon_{\mathrm{j}}\right)$ można wyrazić w skali procentowej i określa on wtedy zwolenników, krytyków oraz postawy neutralne w stosunku do danego rozwiązania. Wykorzystanie współczynnika satysfakcji klientów do oce- ny intensywności wykorzystania przez nich danego kanału dystrybucji umożliwia analizę poziomu ich akceptacji dla tego kanału oraz postrzeganej przydatności danego rozwiązania w systemie sprzedaży wielokanałowej. Oba te elementy kreują wartość dla klienta w sensie funkcjonalnym oraz odzwierciedlają satysfakcję z realizacji zakupów (w sensie emocjonalnym).

Główne wyniki badań, z podziałem na analizowane funkcjonalności systemu sprzedaży wielokanałowej oraz segmenty klientów, zaprezentowano na rysunku 1 . W grupie przedsiębiorstw handlowych postrzegana użyteczność każdego ze składników zintegrowanego systemu sprzedaży jest wyższa niż w przypadku przedsiębiorstw usługowych. Przedsiębiorstwa usługowe oceniają poszczególne funkcjonalności od 3,6 do 8,5\% poniżej średniej z całej próby. Występuje także zróżnicowanie $\mathrm{w}$ ocenie użyteczności poszczególnych funkcji. Zdecydowanie największą użyteczność przedstawiają funkcje prezentacji online towarów dostępnych w sklepach sieci stacjonarnej. Drugą w kolejności jest możliwość zwrotu towarów w sklepach stacjonarnych. Najniżej zostały ocenione funkcjonalności call center oraz wykorzystanie smartfonów w sieci stacjonarnej. Firmy usługowe oceniają funkcje integracyjne $\mathrm{w}$ podobnym rozkładzie ważności, przyznając jednak niższe oceny. Uśredniając uzyskane oceny, obliczono indeks NPS dla obu badanych grup klientów. Dla firm handlowych wynosi on $66,3 \%$, a dla firm usługowych $53,0 \%$. Wyniki te można oceniać jako bardzo pozytywne w aspekcie oceny użyteczności badanych elementów (funkcjonalności) systemu sprzedaży wielokanałowej. Jak wynika bowiem z badań innych autorów, wynik NPS (zarówno na rynku polskim, jak i światowym) na poziomie 50\% można uznać za dobry, a NPS przewyższający 60\% - za bardzo dobry (Kołaciński, 2018; Temkin Group, 2018).

Zestawienie współczynnika integracji kanałów z odchyleniem standardowym pozwala na ocenę homogeniczności odpowiedzi. Analizę danych pod tym kątem przedstawiono na rysunku 2. Punkty wykresu odzwierciedlają odchylenie standardowe $(\mathrm{Y}) \mathrm{w}$ funkcji akceptacji $(\mathrm{X})$ i prezentują odpowiedzi przedsiębiorstw w badanych grupach klientów (kolorem szarym oznaczono odpowiedzi grupy przedsiębiorstw handlowych, zaś kolorem czarnym odpowiedzi firm usługowych). Większość punktów plasuje się w ograniczonym obszarze, co oznacza, że badani są zgodni w swoich opiniach (niskie odchylenie standardowe), oraz wykazują nastawienie pozytywne do badanego zjawiska. Skupiony rozkład punktów oraz jednolity stosunek do poszczególnych funkcji systemu sprzedaży wielokanałowej wykazuje na występowanie akceptacji homogenicznej i pośredniej.

Wyjaśnienie zróżnicowanego poziomu oceny przydatności poszczególnych funkcji może wynikać ze stanu świadomości ankietowanych klientów. Można to rozpatrywać od strony skuteczności zaspokajania ich aktualnych oraz perspektywicznych potrzeb. Klienci mogą oczekiwać zintegrowania systemu sprzedaży przedsiębiorstwa wielokanałowego w celu dostarczenia większej wartości nie tylko teraz, ale także w przyszłości. Zabezpieczy to ich przed koniecznością zmiany dostawcy i ponoszenia kosztów przejścia. Dla każdej grupy klientów może to być inny ze- 


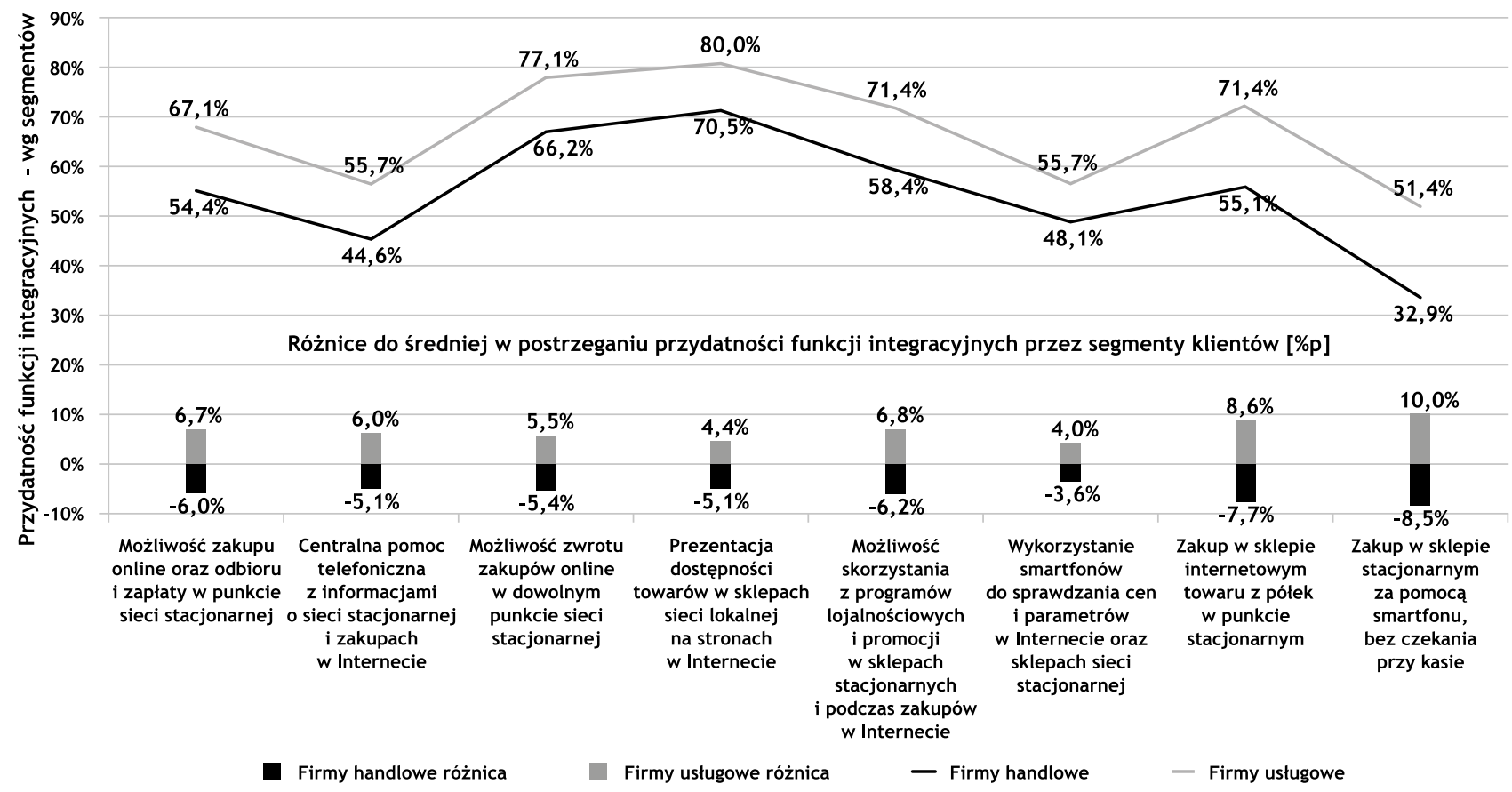

Rys. 1. Przydatność funkcjonalności integracyjnych systemu sprzedaży wielokanałowej

(Wykres słupkowy przedstawia odchylenie ocen firmy handlowych i usługowych od średniej z całej próby)

Źródto: opracowanie wtasne

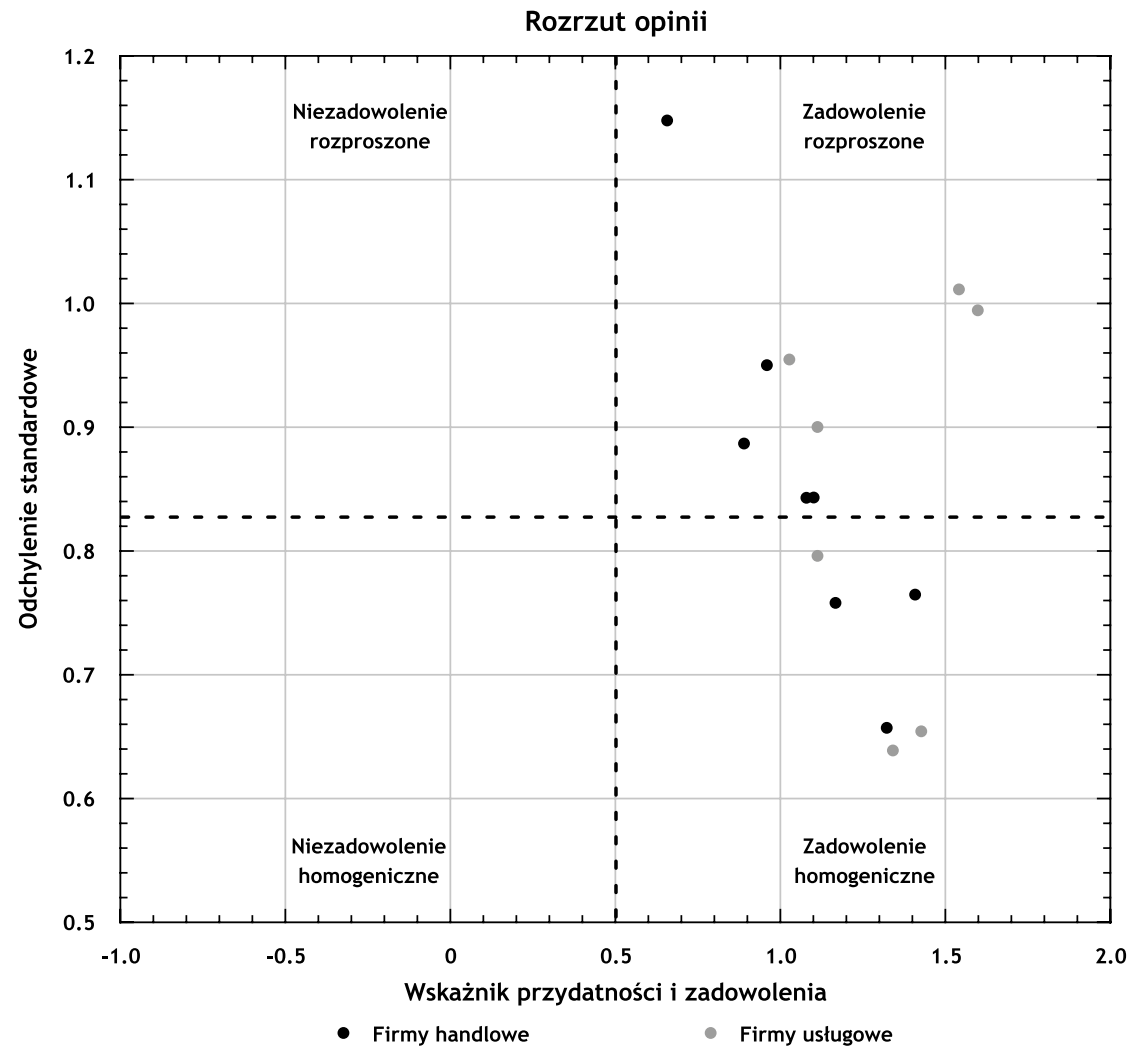

Rys. 2. Ocena akceptacji zintegrowania kanatów Źródto: opracowanie własne 
staw czynników. Modelowe podejście do tego zagadnienia z punktu widzenia specyfiki klientów, które należy rozpatrywać przy konstrukcji modelu biznesowego, przedstawili A. Osterwalder i Y. Pigneur (2010, s. 23). Autorzy wymieniają między innymi takie wartości istotne dla klientów, jak: nowoczesność oferty, wydajność operacyjna, dopasowanie, zaspokojenie potrzeb funkcjonalnych, wzornictwo, marka, redukcja kosztów i ryzyka oraz dostępność i wygoda. Jeśli więc firmy handlowe wysoko oceniają możliwość zakupów online z możliwością odbioru i zapłaty w sklepie sieci stacjonarnej, to oznacza to dla nich wartość w kontekście aktualnych lub perspektywicznych potrzeb. Z kolei opcja click and collect jest korzystna dla dostawcy (dystrybutora) posiadającego sieć sprzedaży stacjonarnej ze względu na możliwość dodatkowej sprzedaży na miejscu. Jest to opcja powszechnie akceptowana na rynku detalicznym (Lockie, 2014, s. 139), ale może mieć też analogiczne znaczenie na rynku biznes-dla-biznesu, o ile dystrybutor ją oferuje. W niektórych segmentach klientów, jak na przykład, w przypadku restauratorów kupujących świeże produkty codziennie, opcja click and collect może być skutecznym sposobem dokonywania regularnych zakupów. Zamówienie wyprzedzające pojawienie się w sklepie pozwala na zaoszczędzenie czasu oczekiwania na spakowanie towaru. W tym przypadku zamówienie internetowe może być wcześniej złożone przez zupełnie inne osoby niż osoby odbierające. Ułatwia też skompletowanie i przygotowanie zamówień do odbioru przez personel sklepu w dogodnym czasie. Wyjaśnienie wysokiej oceny opcji click and collect można także upatrywać w bliskości geograficznej firm i dystrybutorów jako partnerów handlowych. Jeśli magazyn dystrybutora znajduje się w zasięgu ekonomicznie uzasadnionego dojazdu, może on być wykorzystywany podczas poszukiwania towaru dla zaspokojenia niespodziewanych i natychmiastowych potrzeb. Wykorzystanie dostępności w magazynach lokalnych dystrybutora stwarza okazję do szybkiego załatwienia nagłej sprawy bez utraty marży. Wizyty w punktach stacjonarnych dystrybutorów stwarzają także możliwości osobistego porozmawiania $\mathrm{z}$ handlowcami i uzyskania informacji o nowościach w branży i na ryn$\mathrm{ku}$, co stanowi istotną wartość pozamaterialną dla klientów.

Prezentowane badania wskazują na niskie zainteresowanie wykorzystaniem smartfonów do zakupów w sklepach branżowych. Obydwie funkcje związane $\mathrm{z}$ wykorzystaniem smartfonów (tj. funkcja sprawdzania dostępności i samodzielnych zakupów) uzyskały najmniejszą liczbę głosów. Wydaje, się że klienci biznesowi (na rynku B2B) nie traktują smartfonów jako wygodnego i praktycznego narzędzia w obszarze, o który pytano w badaniu. Być może obserwowana popularyzacja samoobsługi na rynku detalicznym z wykorzystaniem smartfonów przyczyni się do wzrostu zainteresowania tą funkcjonalnością także na rynku B2B.

\section{Podsumowanie}

W spółczynnik integracji kanałów jest przydatnym narzędziem analitycznym w opisie wielokanałowego modelu organizacji przedsiębiorstwa. Kumuluje i uśrednia ocenę obszarów funkcjonalnych odpowiedzialnych za jednolite postrzeganie marki. Listę badanych funkcji integrujących można rozszerzać o zagadnienia specyficzne dla danej konfiguracji systemu, co będzie prowadzić do budowy narzędzia badawczego w kontekście określonej strategii zintegrowania kanałów.

Autorzy niniejszej pracy proponują wykorzystanie współczynnika integracji kanałów jako wskaźnika hybrydowego z możliwością jego łatwej dekompozycji. Z jednej strony pokazuje on spójność całego systemu, z drugiej zaś - użyteczność każdej funkcjonalności indywidualnie. Intencją realizacji badań poziomu zintegrowania kanałów było sprawdzenie, w jakim stopniu możliwe jest (zgodnie z definicją omnikanałowości) rozpoczęcie, prowadzenie i zakończenie procesu zakupowego oraz obsługi pozakupowej w dowolnym kanale danego systemu sprzedaży. Integrację kanałów należy więc rozpatrywać kompleksowo, przyjmując jako niezbędne minimum następujące aspekty procesu zakupowego:

- spójność komunikacji do klientów, przekazywanie informacji w jednolity sposób w każdym kanale, ale z uwzględnieniem specyfiki dostępu i możliwości wykorzystania informacji w różnych kanałach,

- organizację procesu zakupowego pod kątem bezproblemowego przechodzenia pomiędzy kanałami na różnych etapach realizacji zakupu, w celu kontynuacji i ostatecznie realizacji zakupu, a także obsługi procesu pozakupowego,

- korzystanie z dostępnych urządzeń, które posiadają klienci oraz do których mają dostęp w sieci stacjonarnej, Internecie lub w innych punktach kontaktu z systemem sprzedaży danego dostawcy,

- wygodę całego systemy dla realizacji celów biznesowych klienta.

Wdrażanie wielokanałowych modeli organizacyjnych nie jest ani tanie, ani proste. Nie można zakładać pełnej akceptacji ze strony klientów - trzeba się liczyć z pojawieniem się niespodziewanych efektów dyssynergii i kanibalizacji. Procesy decyzyjne klientów są ciągle poznawane, ale ulegają też ciągłej ewolucji wraz z rozwojem społeczeństw. W związku z tym wymagane są dalsze badania, zwłaszcza $\mathrm{w}$ powiązaniu $\mathrm{z}$ koncepcjami teoretycznymi dotyczącymi podejmowania decyzji w warunkach ryzyka, w warunkach realizacji procesów $\mathrm{z}$ dużym udziałem technologii, w warunkach występowania inercji wielokierunkowej $\mathrm{z}$ różnymi osobami i podmiotami, księgowania mentalnego itp. Badania takie mogą nie tylko znacznie rozszerzyć zrozumienie przedstawianych zjawisk, ale zwiększyć możliwość poprawy konkurencyjnej przedsiębiorstw, oferujących usługi omnichannel na rynku B2B.

Do najistotniejszych ograniczeń zrealizowanych badań należy m.in. mała próba badawcza, charakter próby i zakres geograficzny. Należy także zwrócić uwagę na fakt, że badania zrealizowano na podstawie analizy odpowiedzi przedstawicieli handlowych przedsiębiorstw, zaopatrujących się $\mathrm{w}$ przedsiębiorstwie, w którym zrealizowano badania. W tym przypadku specyfika relacji B2B stanowi również element, mający wpływ na zakres interpretacji zaprezentowanych zjawisk i procesów. Uwzględnienie tych ograniczeń może stworzyć obszary do kontynuacji 
badań, a w konsekwencji - lepszego zrozumienia zasad kreowania wyższej pozycji konkurencyjnej przedsiębiorstw dystrybucyjnych na profesjonalnym runku.

\section{dr Mieczysław Pawłowski \\ Uniwersytet Marii Curie-Skłodowskiej \\ Wydziat Ekonomiczny \\ ORCID: 0000-0002-9693-0573 \\ e-mail: m.pawlowski@umcs.pl}

\section{dr hab. Zbigniew Pastuszak, prof. uczelni Uniwersytet Marii Curie-Skłodowskiej Wydziat Ekonomiczny ORCID: 0000-0002-8714-3906 \\ e-mail: z.pastuszak@umcs.lublin.pl}

\section{Bibliografia}

[1] Bergevin R., Kinder A., Siegel W., Simpson W. (2010), Call Centers for Dummies, John Wiley \& Sons.

[2] Bezes Ch. (2016), Comparing Online and In-store Risks in Multichannel Shopping, „International Journal of Retail \& Distribution Management", Vol. 44, No. 3, pp. 175-184.

[3] Cao L., Li. L. (2015), The Impact of Cross-channel Integration on Retailers' Sales Growth, "Journal of Retailing", Vol. 91, No. 2, pp. 198-216.

[4] Elektroklub (2017), Dystrybucja artykułów elektrotechnicznych, https://www.elektroklub.pl/aktualnosci/278/dystrybucja-artykun, data dostępu: 23.05.2019 r.

[5] Elektrosystemy (2018), TIM ponownie liderem rankingu „Elektrosystemów”, https://www.timsa.pl/tim-ponownie-liderem-rankingu-elektrosystemow/, data dostępu 23.05.2019 r.

[6] Faltejsková O., Dvorakova L., Hotovcová B. (2016), Net Promoter Score Integration into the Enterprise Performance Measurement and Management System - A Way to Performance Methods Development, „Ekonomie a Management”, Vol. 1, No. 93, pp. 93-107.

[7] Gärdenfors P. (2005), Unreliable Probabilities, Risk Taking, and Decision Making. [in:] The Dynamics of Thought, Synthese Library, Studies in Epistemology, Logic, Methodology, and Philosophy of Science, Vol. 300, Springer, Dordrecht.

[8] Gemius dla e-Commerce Polska, E-commerce_w_Polsce_2018, https://ginter.pro/wp-content/uploads/2018/07/E-commerce_w_Polsce_2018.pdf, data dostępu: 18.06.2019 r.

[9] Herhausen D., Binder J., Schoegel M., Herrmann A. (2015), Integrating Bricks with Clicks: Retailer-level and Channel-level Outcomes of Online-offline Channel Integration, „Journal of Retailing", Vol. 91, No. 2, pp. 309-325.

[10] Kahneman D., Tversky A. (1979), Prospect Theory: An Analysis of Decisions Under Risk, „Econometrica”, No. 47, pp. 263-291.

[11] Kim K.K., Park S.H., Ryoo S.Y., Park S.K. (2010), Inter-organizational Cooperation in Buyer - Supplier Relationships: Both Perspectives, „Journal of Business Research”, Vol. 63, No. 8, pp. 863-869.

[12] Kołaciński J., (2018), Wskaźniki NPS w Polsce. Badania CX, https://yourcx.io/pl/blog/badania-cx/2018/11/wskazniki-nps-w-polsce/, data dostępu: 20.06.2019 r.

[13] Kumar V. (2010), Zarządzanie wartością klienta, Wydawnictwa Profesjonalne PWN, Warszawa.

[14] Lockie W. (2014), Delivering an Effective Click-and-collect Strategy: A Retailer Case Study, „Journal of Digital \& Social Media Marketing", Vol. 2, No. 2, pp. 139-152.

[15] Neslin S.A., Grewal D., Leghorn R., Shankar V., Teerling M.L., Thomas J.S., Verhoef P.C. (2006), Challenges and Opportunities in Multichannel Customer Management, „Journal of Service Research", Vol. 9, No. 2, pp. 95-112.

[16] Neslin S.A., Shankar V. (2009), Key Issues in Multichannel Customer Management: Current Knowledge and Future Directions, „Journal of Interactive Marketing”, Vol. 23, No. 1, pp. $70-81$.

[17] Osterwalder A., Pigneur Y. (2010), Business Model Generation: A Handbook for Visionaries, Game Changers, and Challengers, John Wiley \& Sons.

[18] Pan X., Ratchford B.T., Shankar V., (2004), Price Dispersion on the Internet: A Review and Directions for Future Research, "Journal of Interactive Marketing", Vol. 18, No. 4, pp. 116-135.

[19] Piotrowicz W., Cuthbertson R. (2014), Introduction to the Special Issue Information Technology in Retail: Toward Omnichannel Retailing, „International Journal of Electronic Commerce", Vol. 18, No. 4, pp. 5-16.

[20] Prałat E. (2017), Możliwości elektronicznych zakupów na polskim rynku B2B, „Nierówności Społeczne a Wzrost Gospodarczy", Nr 52, s. 500-510.

[21] Ramanathan R. (2011), An Empirical Analysis on the Influence of Risk on Relationships between Handling of Product Returns and Customer Loyalty in E-commerce, „International Journal of Production Economics", Vol. 130, No. 2, pp. 255-261.

[22] RI Grodno, http://ri.grodno.pl/o-spolce/opis-branzy, data dostępu: 01.06.2019 r.

[23] Systemy Instalacyjne, http://systemy.instalacyjne.pl/?p=5469, data dostępu: 01.06.2019 r.

[24] Temkin Group, (2018), Net Promoter Score Benchmark Study, https://experiencematters.blog/2018/10/01/report-net-promoter-score-benchmark-study-2018/, access date: 20.06.2019.

[25] Thaler R.H. (2008), Mental Accounting and Consumer Choice, „Marketing Science”, No. 1, pp. 15-30.

[26] Verhoef P.C., Kannanb P.K., Inmanc J.J., (2015), From Multi-channel Retailing to Omni-channel retailing: Introduction to the Special Issue on Multi-Channel Retailing, „Journal of Retailing", Vol. 91, No. 2, pp. 174-181.

[27] Verhoef P.C., Neslin S.A., Vroomen B. (2007), Multichannel Customer Management: Understanding the Research-shopper Phenomenon, „International Journal of Research in Marketing", Vol. 24, No. 2, pp. 129-148.

[28] Wang Ch.X., Webster S. (2007), Channel Coordination for a Supply Chain with a Risk-neutral Manufacturer and a Loss-averse Retailer, „Decision Sciences”, Vol. 38, No. 3, pp. 361-389.

[29] Yang S., Lu Y., Chau P.Y. (2013), Why do Consumers Adopt Online Channel? An Empirical Investigation of Two Channel Extension Mechanisms, „Decision Support Systems”, Vol. 54, No. 2, pp. 858-869. 
Channel Integration in Omnichannel Retailing

\section{Summary}

In relation to growing popularity of e-commerce, we can observe a transformation of retail sales organisations into the omnichannel operating model. The uniqueness of the value proposition, which they create in this approach, results from the synchronised ecosystem which is able to deliver a seamless shopping experience to customers. Retailers utilise different forms of multichannel communication in combination with organisational effectiveness for leveraging the value bunch, market position and the scale of operation.
The authors explore business model integration as the core of customer experience creation in a business-to-business relationship. The results of investigation (surveys) have demonstrated that customers evaluate highly the integrated service model only when it links a proper product offer with operational effectiveness. The level of integration determines model attractiveness for customers in terms of convenience, product mix and service quality. Finally, well integrated omnichannel organisation creates competitive advantages on the market which results in exceptional value capture for shareholders.

\section{Keywords}

omnichannel, business model, channel integration, B2B 